\title{
Primary cutaneous follicle center lymphoma simulating basal-cell carcinoma on the nasal ala*
}

\author{
Mariana Isis Wanczinsnki ${ }^{1}$ \\ Flávia Trevisan² \\ Luz Marina Hannah Grohs ${ }^{1}$
}

\author{
Clóvis Antonio Lopes Pinto ${ }^{1}$ \\ Paulo Rowilson Cunha ${ }^{1}$
}

DOI: http:/ / dx.doi.org/ 10.1590/ abd1806-4841.20153768

\begin{abstract}
Primary cutaneous B-cell lymphomas (PCBCLs) constitute $25 \%$ of all primary cutaneous lymphomas. They present in the skin with no evidence of systemic or extracutaneous disease at the time of diagnosis, after adequate staging. Primary cutaneous B-cell lymphomas differ significantly from their nodal counterparts in relation to both clinical behavior and prognosis. Thedistinction between primary and secondary B-cell lymphomas is essential for defining prognosis/ course of action. Such distinction is also very difficult to make, since primary and secondary B-cell lymphomas are clinically and histologically indistinguishable. We report the case of a patient with primary cutaneous follicle center lymphoma who underwent surgical excision.
\end{abstract}

Keywords: Carcinoma, basal cell; Lymphoma, B-cell; Lymphoma, B-cell, marginal zone; Lymphoma, follicular; Lymphoma, non-Hodgkin; Precursor cell lymphoblastic leukemia-lymphoma

\section{INTRODUCTION}

The lymphomas are a group of neoplasms arising from the lymphoreticular system. They are divided into two main groups: Hodgkin's lymphoma (HL) and non-Hodgkin lymphomas (NHL). The latter may be nodal (when primarily involving the lymph nodes) or extranodal. ${ }^{1}$ A bout $30 \%$ of $\mathrm{NHL}$ involve extranodal tissues. The skin is the second most affected organ (after the gastrointestinal tract), comprising approximately $18 \%$ of these lymphomas. ${ }^{2}$

Based on their cellular origin and according to the expressed monoclonal antibodies, Iymphomas can be divided into T- or B-cell lymphomas. ${ }^{1,3}$ The expression of CD3, CD4, CD8, CD43 or CD45 confirms their T-cell character. The expression of CD20, in particular, but also of CD79, CD5 and CD10 confirms their B-cell character. ${ }^{3}$ Cutaneous B-cell lymphomas (CBCL) are less frequent than cutaneous T-cell lymphomas, rep- resenting about $25 \%$ of all cutaneous lymphomas. It shows a slight pREFERENCES for males and an increased incidence with age. ${ }^{1}$

CBCL can be primary or secondary. Primary $\mathrm{CBCL}$ have a more indolent natural history than secondary CBCL and a good prognosis. They are characterized by having only cutaneous presentation, with no evidence of extracutaneous lesion after adequate staging. They have an identical morphological appearance but different clinical behaviors. ${ }^{1}$

In 2005, the World Health Organization (WHO) and the European Organization for Research and Treatment of Cancer (EORTC) proposed a classification for primary cutaneous lymphomas. CBCL were divided into marginal zone, follicle center, diffuse large B-cell, leg type and intravascular large B-cell lymphoma (Chart 1). 1,4

\footnotetext{
Received on 14.06.2014

A pproved by the Advisory Board and accepted for publication on 23.07.2014

Study conducted at the Faculty of Medicine of Jundiaí (FMJ) - Jundiaí (SP), Brazil.

Financial Support: None.

Conflict of Interest: None.

Faculdade de Medicina de Jundiaí (FMJ) - Jundiaí (SP), Brazil.

Universidade Federal do Paraná (UFPR) - Curitiba (PR), Brazil.

(C2015 by A nais Brasileiros de Dermatologia
} 
Chart 1: Classification of cutaneous lymphomas (WHO/ EORTC, 2005)

\begin{tabular}{|c|c|}
\hline Neoplasms of mature T and NK cells & $\begin{array}{l}\text { Mycosis fungoides } \\
\text { Variants of mycosis fungoides } \\
\text { Subtype of mycosis fungoides } \\
\text { Sezary syndrome } \\
\text { CD30-Positive T-Cell Lymphoproliferative Disorders } \\
\text { Subcutaneous panniculitis-like T-cell lymphoma } \\
\text { Peripheral t-cell lymphoma, non specific } \\
\text { Extranodal NK/ T-cell lymphoma, nasal type } \\
\text { Adult T-cell leukemia / lymphoma } \\
\text { Extracutaneous lymphomas, usually with skin involvement }\end{array}$ \\
\hline B-cells neoplasms & $\begin{array}{l}\text { Cutaneous marginal zone B-cell lymphoma (M ALT type) } \\
\text { Primary cutaneous follicle center lymphoma } \\
\text { Follicular } \\
\text { Follicular and diffuse } \\
\text { Diffuse } \\
\text { Cutaneous large B-cell lymphoma } \\
\text { Leg type } \\
\text { Others } \\
\text { Intravascular large B-cell lymphoma }\end{array}$ \\
\hline Immature hematopoietic malignancies & $\begin{array}{l}\text { Blastic NK cell lymphoma / CD4+/ CD56+ hematodermic neoplasia } \\
\text { Lymphoblastic precursor lymphoma/ leukemia } \\
\text { T-cells } \\
\text { B-cells }\end{array}$ \\
\hline
\end{tabular}

Source: Burg G, 2005.4

We report the case of a patient with primary cutaneous follicle center lymphoma (PCFCCL), the most common type of $\mathrm{CBCL}$, which occurs primarily in the skin and whose clinical manifestations can mimic many other diseases. In our case, the main differential clinical diagnosis was basal cell carcinoma.

\section{CASE REPORT}

A 65-year-old white male patient had had an asymptomatic, smooth-surfaced, erythematous nodular lesion of $1.2 \mathrm{~cm}$ in diameter, with telangiectasia and progressive growth on the left nasal ala for eight months (Figure 1). The initial diagnostic hypothesis was basal cell carcinoma. Histopathological examination revealed a preserved dermis and epidermis with formation of lymphoid follicles. Lymphocytic cells were identified both in the periphery and center of the follicle (Figure 2). Immunohistochemistry was positive for CD20, CD10 and BCl-6 in cells of the germinal center and negative for $\mathrm{BCl}-2$, thus confirming the diagnosis primary cutaneous follicle center lymphoma (Figure 3). Laboratory tests showed normal blood

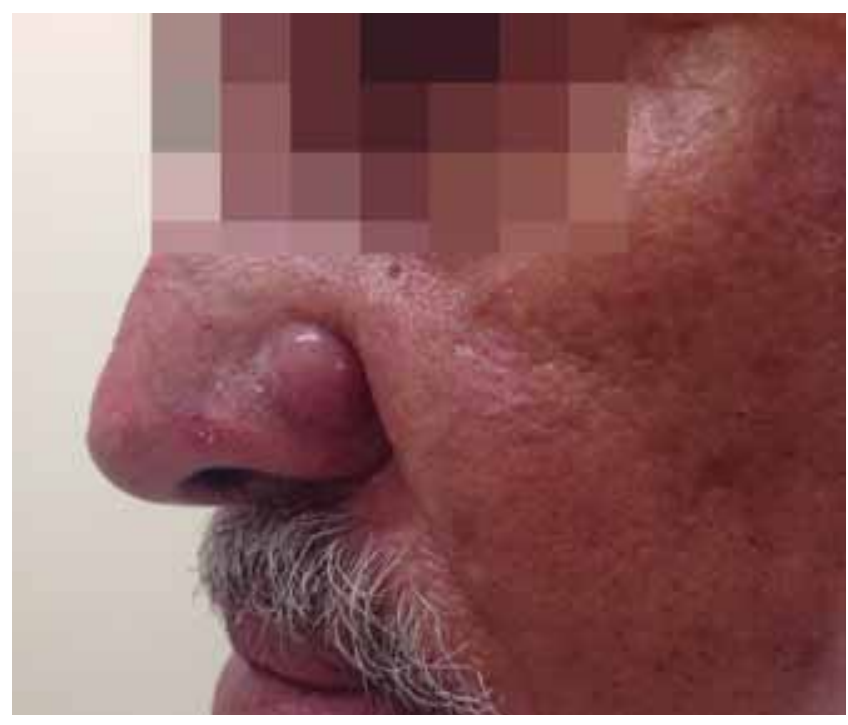

Figure 1: Clinical view of the PCFCCL: smooth-surfaced, erythematous nodular lesion of $1.2 \mathrm{~cm}$ in diameter, with telangiectasia on the left nasal ala 


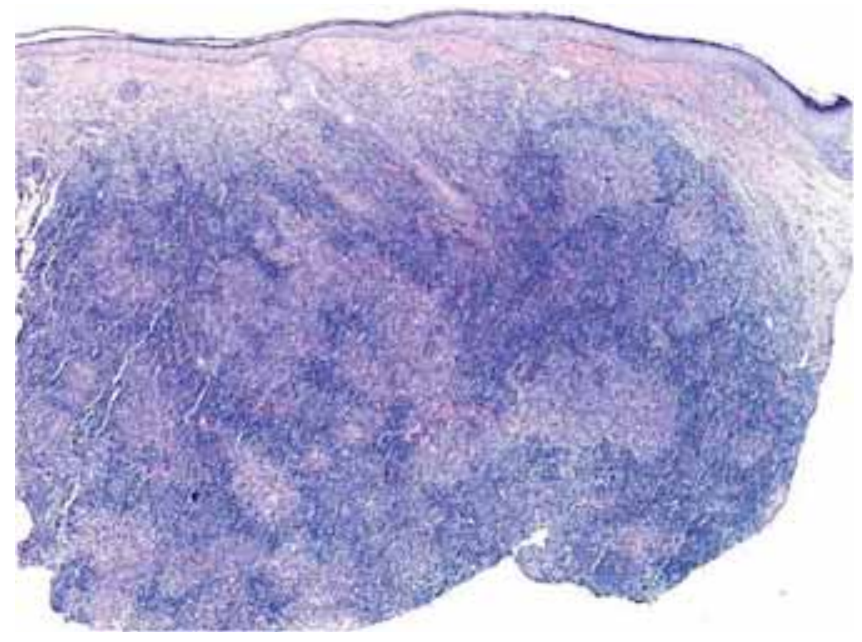

Figure 2: Histopathology of the PCFCCL: preserved dermis and epidermis with formation of lymphoid follicles. Lymphocytic cells were identified both in the periphery and center of the follicle. Hematoxylin-eo$\sin , 40 \mathrm{X}$

count and normal Lactate Dehydrogenase (LDH) levels, negative VDRL test, and negative anti-HIV and anti-HTLV 1 antibodies. CT scans of the chest/ abdomen and pelvis showed no signs of malignancy and the bone marrow biopsy/ aspirate showed no abnormalities. The patient underwent surgical excision of thelesion (Figure 4).

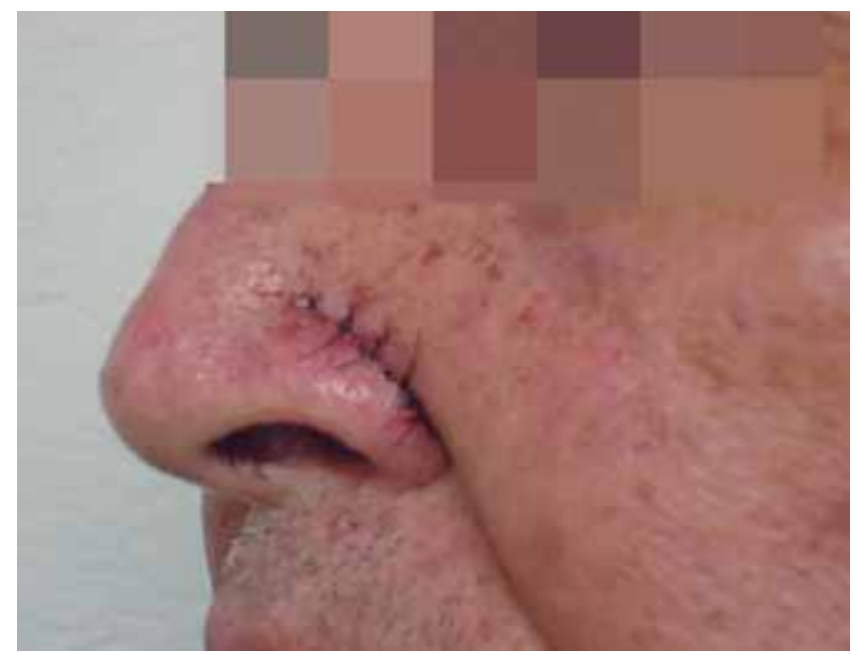

Figure 4: Seventh post-operative day after surgical excision with primary closure of the lesion on the left nasal ala. Linear incision showing good healing and the presence of suture stitches

\section{DISAUSSION}

PCFCCL represent $55 \%$ of of all CBCL. They have a predilection for males and mainly affect adults with an average age of 60 years. Clinically, it manifests itself as solitary or grouped, erythematous to violaceous papules, plaques, nodules or tumors. They rarely ulcerate or exhibit necrosis. The lesions occur
A
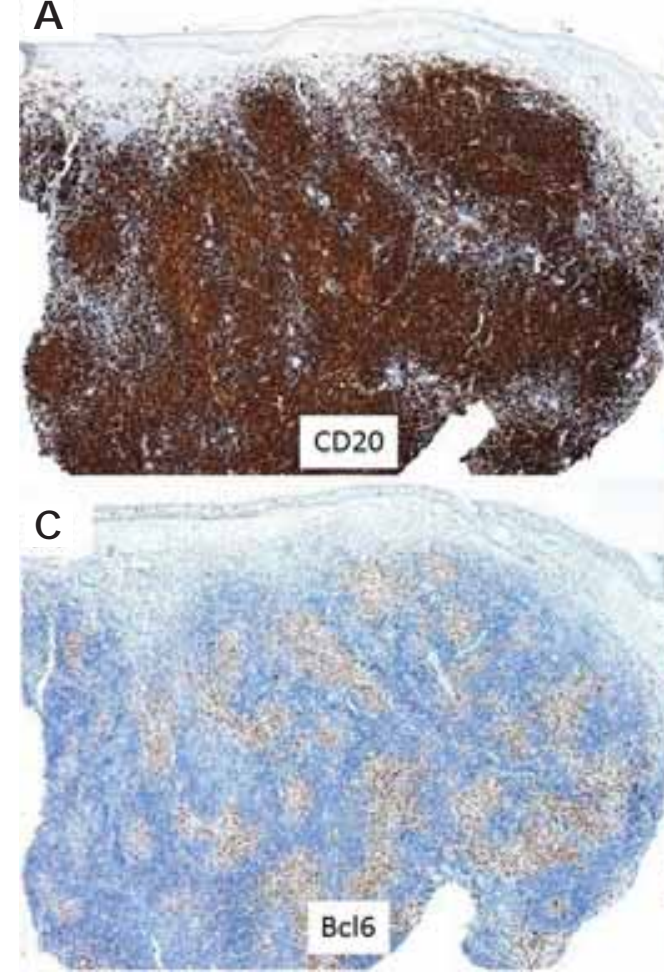
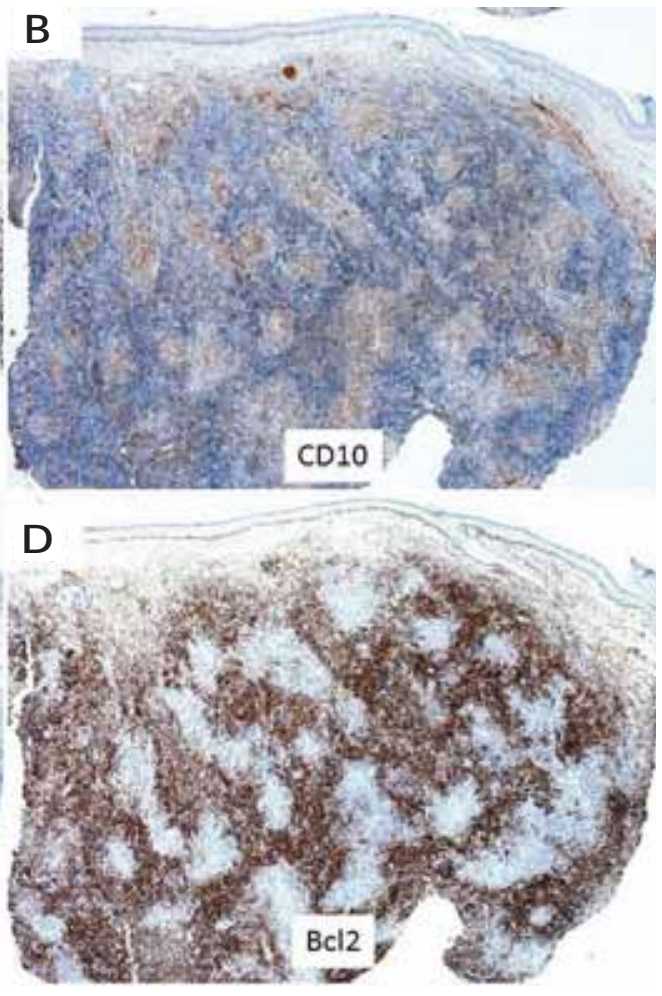

\section{Figure 3:}

Immunohistochemistry of the PCFCCL: (A) the cytoplasm of B-cells was strongly positive for CD20. (B) germinal center cells were positive for CD10. (C) germinal center cells were positive for Bcl-6. (D) germinal center cells were negative for $\mathrm{Bcl}-2$. Immunohistochemistry, 40X 
mainly on the head, neck and trunk. The differential diagnosis includes inflammatory lesions such as acne, epidermal inclusion cyst, and lymphoid hyperplasia, and cutaneous malignancies such as basal cell carcinoma. ${ }^{1,3}$ In the case presented here, the first diagnostic hypothesis was basal cell carcinoma. Diagnostic differentiation was carried out by means of histology, immunohistochemistry and staging tests.

The five year survival rate is over $95 \%$. Spread to lymph nodes or internal organs is rare (5\%). The recurrence rate is high (about $50 \%$ ), but there is not a worse prognostic factor and it is usually confined to skin. ${ }^{1,2}$ Histologically, it presents dermal and subcutaneous proliferation of centrocytes and centroblasts in a follicular and/ or diffuse growth pattern. The tumor cells express B-cell markers such as
CD20, CD79a, CD10, Bcl-6 and negativity for Bcl-2. ${ }^{1}$ For single lesions, as in the case reported here, the first choice of treatment is radiotherapy or surgical excision. ${ }^{2}$

Differentiating between primary and secondary skin involvement, through undiagnosed nodal or visceral malignancies, is crucial in addressing CBCL, because of the difference in prognosis and therapeutic options, given that primary and secondary B-cell lymphomas are clinically and histologically indistinguishable. ${ }^{1,2,3,4}$ In the past, it was believed that CBCL were invariably secondary. In recent years, however, it has been recognized that $C B C L$ whose primary site is the skin represent a distinct and very important group of extranodal lymphomas. ${ }^{1,3,4} \square$

\section{REFERENCES}

1. Suárez AL, Pulitzer M, Horwitz S, Moskowitz A, Querfeld C, Myskowski PL. Primary cutaneous B cell lymphomas. Part I. Clinical features, diagnosis and classification. J Am Acad Dermatol. 2013;69:329.e1-13.

2. Suárez AL, Querfeld C, Horwitz S, Pulitzer M, Moskowitz A, Myskowski PL. Primary cutaneous B cell lymphomas. Part II. Therapy and future directions. J Am Acad Dermatol. 2013;69:343.e1-11.

3. Sampaio SAP, Rivitti EA. Leucemias, Linfomas e Pseudolinfomas. In: Sampaio SAP, Rivitti EA. Dermatologia. 2. ed. São Paulo: Artes Médicas; 2000. p.887-913.

4. Burg G, Kempf W, Kazakov DV, Michaelis S, Dummer R. WHO/EORTC Classification of Cutaneous Lymphomas. In: Burg G, Kempt W. Cutaneous lymphomas. Florida: Taylor \& Francis Group; 2005, 91-92.
M AILING ADDRESS:

Flávia Trevisan

Rua Francisco Telles, 250

Vila A rens

13202-550 Jundiaí - SP

Brazil

E-mail: flaviatrevisan1@gmail.com

How to cite this article Wanczinski MI, Pinto CAL, Trevisan F, Cunha PR, Grohs LMH. Primary cutaneous follicle center lymphoma simulating basal-cell carcinoma on the nasal ala . An Bras Dermatol. 2015;90 (3Suppl 1):S111-4. 